\title{
DECISION-MAKING FACTORS IN CONSUMER BEHAVIOUR ON THE MARKET WITH DECORATIVE COSMETICS
}

\author{
${ }^{a}$ VERONIKA MACHOVÁ, 'VERONIKA ŠANDEROVÁ, \\ 'DOMINIKA MRKVIČKOVÁ \\ ${ }^{\mathrm{a}, \mathrm{b}, \mathrm{c}}$ Institute of Technology and and Business in České \\ Budějovice, School of Expertness and Valuation, Okružní \\ 517/10, 37001 České Budějovice, Czech Republic \\ email: ${ }^{a}$ machova@mail.vstecb.cz, ${ }^{b}$ 28322@mail.vstecb.cz, \\ c27257@mail.vstecb.cz
}

\begin{abstract}
The article explores major decision-making factors in consumer behaviour when purchasing decorative cosmetics. The employed methods involve brainstorming and structured interviews. The most powerful internal stimuli are body care and and structured interviews. The most powerful internal stimuli are body care and looking good. On the other hand, a desire to try a new cosmetic product plays a rather subordinate role. The main external purchasing factors involve a recommendation from a friend or relative. On the contrary, aspects such as vegan composition of the product or its packaging do not attract much attention. However, research conclusions cannot apply on the long-term basis given to the rapid development of new mperative to monitor the current market trends.

Keywords: consumer behavior, marketing, brainstorming, Word of Mouth, influencering
\end{abstract}

\section{Introduction}

Consumer behavior has always been a burning marketing issue. Companies examine hidden motives that influence customer's decision-making. These purchasing stimuli help organizations develop more effective marketing strategies to break into the competitive market. The huge challenge for all businessmen is thereby to attract consumers to buy their products or services. It involves a deep psychological insight into consumer's mind, thinking, feeling, arguments and decision between available alternatives. What also needs to be considered is consumer's immediate environment such as culture, family and influencing media. All these aspects are imperative to launch a vigorous marketing campaign aiming at consumers (Stankevich, Akhunjonov and Obrenovic, 2017; Kicová, 2020).

Consumers nowadays have an infinite number of opportunities what to purchase. In view of the fact that products are very similar and with no significant differences in quality or price, the choice depends on more than 'traditional' variables (WillmanIivarinen, 2017; Nadányiová, Klieštiková and Olah, 2019).

All people are consumers but, at the same time, they consider different factors that influence their purchasing behavior. A reasonable consumer is rational, seeking the maximum use of the product, involving material possession and related services. The determining aspects include consumer's financial resources, availability of the product, overall company supply and customer marketing communication. These criteria comprise marketing mix 4P (Novotný and Duspiva, 2014).

The article intends to evaluate consumer behavior when purchasing decorative cosmetics based on specific decisionmaking factors.

RQ1: Which and how internal motives prompt a customer to buy decorative cosmetics?

RQ2: Which and how external factors prompt a customer to buy decorative cosmetics?

RQ3: What is the difference in consumer behavior on the market with decorative cosmetics throughout age categories?

\section{Literature research}

Looking through shelves, a consumer can see up to 300 different products per minute. Such a gargantuan bulk of merchandise effectively prevents brands from capturing his attention. The competition within such an exorbitantly stimulated environment is extremely fierce and engaging packaging appears to be the best weapon. The significance of marketing product encapsulating was subjected to a careful examination revealing that not only package neatness, safeness, convenience and product commercialization, but also brand identity, attractiveness and explicit category can win the battle. Moreover, a type of packaging is imperative for product added value and consumer behavior. Some previous researches on product packages emphasized multi-functionality, while others compared different package types and their influence on consumer behavior (color, shape, size, pictures etc.). Most studies confirmed that product coverings are essential in consumer's decision-making, as attractive containers may hugely encourage the purchase. Appealing wrappers are not thereby only a powerful competition tool, but also a strategic instrument to identify and decide between products by breaking away from a rivalling chaotic selection in a shop or supermarket (Moya, García-Madariaga and Blasco, 2020).

There was a time when scientists formulated general theories within the framework of consumer behavior. Modern science focuses more on specific determinants and relations, effectively dealing with interdisciplinary issues such as neuroscience. This penetration gave the grounds to other academic spheres, e.g. neuromarketing. This new branch explores functioning of human brain and responds to marketing stimuli using neuroscientific principles. (Stankevich, Akhunjonov and Obrenovic, 2017). Neuromarketing presents a field of study that applies neuroscientific methods to analyze and understand human behavior relating to marketing (Bočková, Škrabánková, Hanák, 2021). These techniques only supplement and develop other methodologies of consumer behavior, for example observation, surveys and questionnaires (Maynard et al. 2019).

The rapid development of the internet and smart technologies effected dramatic changes in human lives in the last two or three decades. This abrupt technological transition had a profound impact on culture and social trends, and consumer behavior was not an exception. Irrespective of great technological boom, it is assumed that consumer behavior has not been significantly affected; however, there was a drastic change in exploiting resources. Rapid technological development, social trends, varied selection of goods and services and economic boom factor in a sudden twist in purchasing behavior on the market. Marketing managers have to adapt to the changing lifestyle and consumer behavior (Žák and Hasprová, 2020; Král et al. 2020). Social networks and online marketing present another crucial aspect to consider. Shrewd businessmen seek cooperation with influential people, instead of chasing after potential purchasers. Prominent personalities promote products with the view to persuading consumers to a purchase. The personages are chosen by their popularity, reputation or professional knowledge. This type of marketing is called WOM (word-of-mouth marketing).

Branding (using celebrities to promote a product) has become increasingly popular not only with bloggers, but also common users who have great influence on others. Influencer marketing is the most successful strategy for addressing new consumers by online media. A lot of influencers are also bloggers - people who share experience, stories or interests with wider internet community. Many of them had not been regular influencers and only had pursued their scope of interests. These people involve sportsmen, actors, adventurers or mothers on the maternity leave. Each of them can aim at a specific group of people and promote a different product. The innermost core of influencer marketing consists in a good product promotion, which means that the influencer must identify with the advertised goods to eliminate doubts about his/her experience or, even, knowledge about the commodity (Žák and Hasprová, 2020; Slabá, 2019). Social media also allow entrepreneurs to maintain an enduring relationship with customers and respond promptly to growing demands. This represents another critical element involved in consumer behavior (Mazeed et al. 2019). On the other hand, 
these communication channels could be for some types of people addictive and dangerous (Porter et al. 2020).

Word-of-mouth (WOM) communication presents a different convenient method of controlling consumer behavior. WOM may be defined as "informal verbal communication established either face-to-face, or by phone, e-mail, addressee register or another communication technique". WOM is an invaluable data source created by individuals or businessmen through which the acquired information is forwarded to other users. WOM's main goal is to make consumers highly knowledgeable about products or services before the commodity or service is used. WOM communication content brings positive or negative information about providers, products or services. Positive or negative data stored on WOM and observing purchase of other consumers have a deep impact on individual's purchasing behavior (Wang and $\mathrm{Yu}, 2017$ ).

Enterprises should also maintain a close relationship with customers to inspire intense loyalty a consumer displays to a specific product or services. Above all, it involves direct communication and keeping customers satisfied (Sun, 2020). Customer Relationship Management (CRM) is an effective tool to build up long-standing relationships including loyalty, performance or incentive bonuses, which also control consumer behavior. These benefits offer discounts or points traded for products or services provided by the company to win stakeholders' loyalty (Filipe, Marques and Salgueiro, 2017; Žilinská, Vrbka and Kalinová, 2021).

Marketing solely aims at addressing consumers at the moment of making a decision - they are suspectible to controlling (so called 'breaking points' or 'contact points'). These very moments are much sought after (Stankevich, Akhunjonov and Obrenovic, 2017).

The data on consumers are acquired and processed through a structured interview with a subsequent evaluation of factors dramatically influencing consumer behavior on the market with decorative cosmetics.

\section{Data and methods}

The relevant data were amassed through brainstorming and structured interview with customers. Pertinent questions included in the interview aimed at capturing data from respondents which were further analyzed and evaluated according to the set objectives and research questions, all relating to consumer behavior on the market with decorative cosmetics.

We started with brainstorming when respondents answered research questions concerning internal motives, and external stimulating factors leading to the purchase. This extensive mass of data collected from respondents gave sufficient grounds to a structured interview which took place in České Budějovice in the Czech Republic in April 2020. The systematic survey primarily covered women throughout age categories which commonly use decorative cosmetics - 15 respondents in total. The first question concerned whether the consumer is suitable for the research. If so, selected respondents were further divided into age categories as follows: less than 25 years, 26-40 years and 41 and more years. Each group involved five respondents who provided data on their consumer behavior in specific age groups. The next part contains the rated answers.

Four selected respondents engaged in brainstorming aiming at internal motives and external stimulating factors for purchasing decorative cosmetics. The acquired data comprise statistical tables showing inner stimuli and external aspects for buying decorative cosmetics. The information from the graph contributed to the structured interviews.

Firstly, all respondents were confronted with the introductory question: "Do you buy decorative cosmetics?" If the woman answered 'yes', we could hold the interview. What followed were inquiries on age by which we could compare differences in consumer behavior depending on the age. Compiled graphs contained alternatives evaluated on a scale $0-10$ according to the importance (0-no influence, 10-great influence). The gathered and examined data gave grounds to the arithmetic mean of individual motives and factors relating to consumer behavior. Drawn-up pie graphs illustrate the structure of internal motives and external factors of respondents' consumer behavior with a subsequent comparison of differences between separate age categories.

\section{Results}

Brainstorming and collected data constitute two tables used in the follow-up conversation. Table 1 refers to the most frequent internal motives for buying decorative cosmetics scaling from 0 to 10 .

Table 1: The most frequent internal motives for the decorative cosmetics purchase

\begin{tabular}{|c|c|c|c|c|c|c|c|c|c|c|c|}
\hline \multirow{2}{*}{ Internal motives } & \multicolumn{10}{|c|}{ Rating } \\
\hline & 0 & 1 & 2 & 3 & 4 & 5 & 6 & 7 & 8 & 9 & 10 \\
\hline Pleasure & & & & & & & & & & & \\
\hline Body care & & & & & & & & & & & \\
\hline Feeling good & & & & & & & & & & & \\
\hline $\begin{array}{c}\text { Looking good } \\
\text { for myself }\end{array}$ & & & & & & & & & & & \\
\hline $\begin{array}{c}\text { Looking good } \\
\text { for others }\end{array}$ & & & & & & & & & & & \\
\hline $\begin{array}{c}\text { Need for } \\
\text { purchase }\end{array}$ & & & & & & & & & & \\
\hline $\begin{array}{c}\text { Desire to try a } \\
\text { new product }\end{array}$ & & & & & & & & & & \\
\hline
\end{tabular}

Source: Authors.

Table 2 concerns information on the external factors gathered from brainstorming. Table 2 shows the most frequent internal motives for buying decorative cosmetics scaling from 0 to 10 .

Table 2: The most frequent external stimuli for purchasing decorative cosmetics

Source: Authors

\begin{tabular}{|c|c|c|c|c|c|c|c|c|c|c|c|}
\hline \multirow{2}{*}{ External factor } & 0 & 1 & 2 & 3 & 4 & 5 & 6 & 7 & 8 & 9 & 10 \\
\hline Advertisement & & & & & & & & & & & \\
\hline Price & & & & & & & & & & & \\
\hline Packaging & & & & & & & & & & & \\
\hline Brand & & & & & & & & & & & \\
\hline Influencer & & & & & & & & & & & \\
\hline $\begin{array}{c}\text { Special offer/loyalty } \\
\text { club }\end{array}$ & & & & & & & & & & & \\
\hline Review & & & & & & & & & & & \\
\hline $\begin{array}{c}\text { Friend/family } \\
\text { recommendation }\end{array}$ & & & & & & & & & & & \\
\hline No animal testing & & & & & & & & & & & \\
\hline Vegan cosmetics & & & & & & & & & & & \\
\hline Materials used & & & & & & & & & & & \\
\hline
\end{tabular}

The following pie graphs of separate age categories were compiled according to interviews and rating of internal motives and external factors. Graph 1 shows the most and least frequent internal stimuli for the age up to 25 years. The research revealed that the need for looking good for others is the strongest motivation, followed by the desire to try a new product or give pleasure. The average frequency was marked in a need for a purchase, while the last place was taken by the entry feeling good. What was also met with a negligible significance was body care and the need for looking good to myself. 
Graph 1: Internal motives of respondents up to 25 years

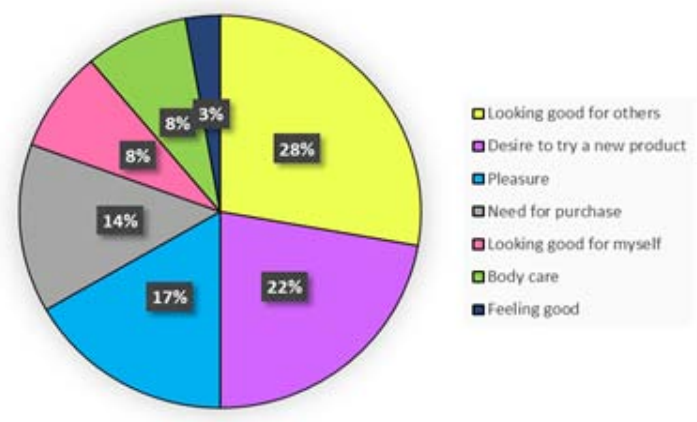

Source: Authors.

Graph 2 indicates the most and least significant external factors that prompt respondents in the age up to 25 years to buying decorative cosmetics. The survey revealed a product promoted by an influencer or celebrity and a recommendation from a friend or family as the most relevant factors. These two aspects were awarded 10 points by most respondents. Price, special offers or loyalty club shared the second place within the same category. The average influence on consumer behavior was exerted by product packaging, internet reviews and advertisement. Of minor significance is a specific brand where interviewees emphasized their overall satisfaction with the product rather than a particular brand. On the other hand, the respondents completely disregarded factors such as no testing on animals, materials used or vegan cosmetics, asserting no interest in looking for this information.

Graph 2: External factors of respondents up to 25 years

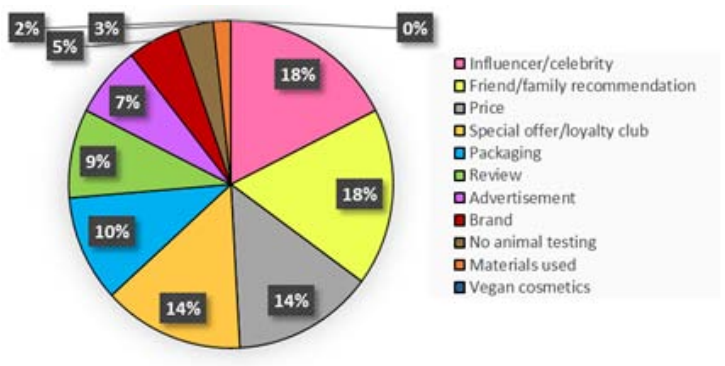

Source: Authors.

Graph 3 refers to internal motives involved in consumer behavior of respondents in the age between 26 and 40 years. Women within this category mostly emphasize entries such as looking good for myself and body care. The second place is occupied by the need for a purchase of decorative cosmetics and feeling good. On the other hand, interviewees do not pay special attention to looking good for others. The last position is held by taking pleasure from the purchase of a cosmetic commodity and the desire to try a new product.

Graph 3: Internal motives of respondents between 26 and 40 years

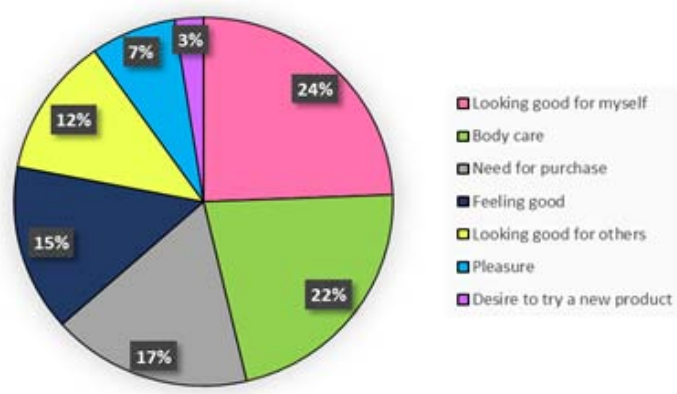

Source: Authors
Graph 4 suggests external factors influencing consumer behavior within the category in question. The interviewed women marked recommendation from a friend or family and promotion of an influencer or celebrity as the most frequent decisive determinants, mostly scaling with 8-10 points. Other crucial external stimuli involve internet reviews, special offers, loyalty clubs or price. Aspects with only a subtle effect include a brand and no animal testing. On the other hand, criteria such as packaging, materials used and vegan cosmetics are of negligible or no effect at all.

Graph 4: External factors of respondents between 26 and 40 years
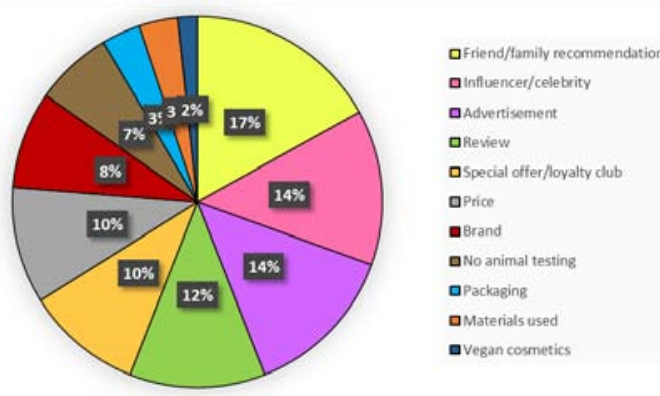

Source: Authors

Graph 5 suggests the results of the strongest internal motives from the last examined group - respondents from 41 years and more. The questioned women go mostly after body care and feeling good. The second highest motivation is to take pleasure, followed by looking good for myself. On the other hand, the women do not pay special attention to looking good for others. The absence of any motivation was detected in the need for a purchase and desire to try a new product, both scaling with rates 1 or 2.

Graph 5: Internal motives of respondents of 41 years and more.
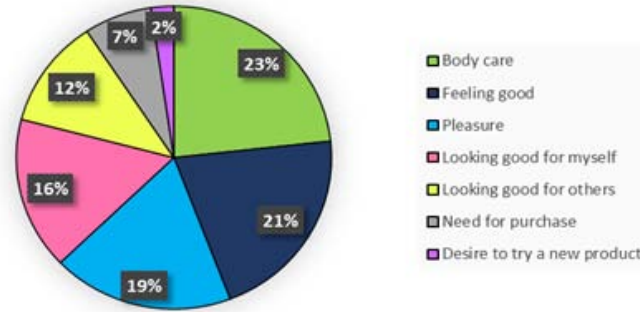

Source: Authors.

The last diagram, Graph 6, refers to external factors influencing the purchase of decorative cosmetics in the category of 41 years and more. The survey showed that the respondents feel the strongest inclination to a specific brand. The second rank is held by the materials used in the product, vegan commodities, recommendation from a friend or family and whether the products had been tested on animals. On the other hand, the questioned women showed only a slight tendency for acting upon advertisement, internet reviews or price. Of negligible significance is a special offer, loyalty club or product packaging, whereas the entry concerning influencers or celebrities promoting a product scaled down to zero. 
Graph 6: External factors of respondents from 41 years and more
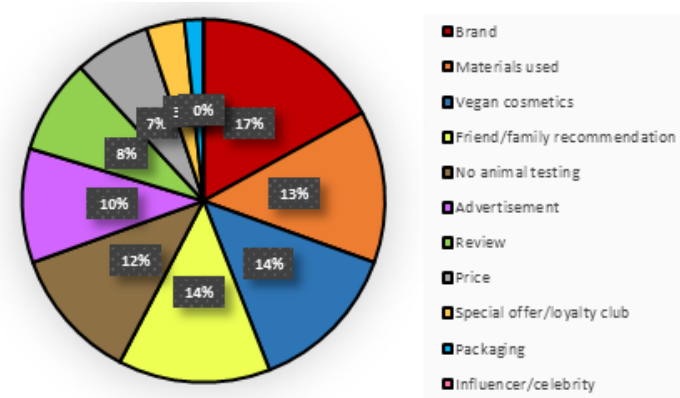

Source: Authors.

\section{Discussion}

The achieved results provided answers for the formulated research questions.

RQ1: What and how internal stimuli motivate customers to purchase decorative cosmetics?

The most frequent internal motives persuading respondents into the purchase of decorative cosmetics are as follows: body care, need of looking good for myself, need of looking good for others, feeling good, desire to try a new products, need for a purchase and take pleasure from the bargain. Although individual respondents have various priorities, their motives for a purchase may vary on the day-to-day basis. Women also mentioned incentives not involved in the survey, such as reaping the rewards for hard work, when shopping satisfactorily does the trick. Sometimes, they only want to address the material need for the product, or they just wish to raise a spirit and feel good. The gathered data were compared with the results of other authors. Hamplová (2017) in her survey on the same topic received similar answers. For example, the category of internal stimuli involved hands-on experience with the purchase, which ranked very high. The highest rated internal motives encouraging respondents' consumer behavior were body care and looking good for myself, whereas the least frequent stimulus fell on the desire to try a new product.

RQ2: Which and how external factors stimulate a customer to purchase decorative cosmetics?

The research revealed that respondents put heavier emphasis on external factors than on internal motives when buying decorative cosmetics. Most women even admitted to not planning to buy a cosmetic product, but a special offer or another external stimulus often persuades them into the bargain. The most frequent external factors involve: brand, price, friend's or family's recommendation, reviews, a product promoted by an influencer or celebrity, materials used, package, no animal testing, vegan cosmetics, special offer/loyalty club and advertisement. Recommendation from a friend or family scored the highest rating, which is in compliance with questionnaire results achieved by Hamplová (2017). On the other hand, factors such as package, special offer or advertisement do not play any role, which is in conflict with the obtained results. The interviews proved these factors imperative, while the questionnaire ranked them as completely insignificant. It again depends on diverse priorities of the respondents, whose consumer behavior is influenced by different factors and different information about the purchased product. Other external stimuli included in the questionnaire are product quality, country of origin, magazine or expert's opinion (e.g. beauticians). The recommendation from a friend or family member was the most decisive external factor in interviews, whereas vegan cosmetics, product packaging and materials used scaled with the lowest values.

RQ3: What is the difference in consumer behavior on the market with decorative cosmetics throughout age categories?
Firstly, a detailed analysis examined the differences in the internal motives inducing respondents to a purchase. The sharpest contrasts appeared in entry 'looking good for others'. Women up to 25 years rated the incentive as very important, while other age categories did not seem motivated by this stimulus at all. The next internal motive inconsistent in overall rating is feeling good. This aspect is considered essential in the category of 41 years and more, whereas respondents up to 25 years did not assign this incentive any significance. Other huge discrepancies occurred in entry 'desire to try a new product', which is again meaningful only to the youngest category. Other age groups do not find this factor very attractive. Although the decision-making process of individual respondents showed substantial differences, there was an internal consistency within particular age groups in motives encouraging the purchase in question

What follows is a closer look on distinctions in consumer behavior depending on external stimulating factors. A marked inequality was spotted in seeking the information on materials used in a product, whether a commodity was tested on animals or if vegan merchandise is to be dealt with. The stimuli at issue were crucial neither for the category up to 25 years, nor the group of 26-40 years. On the other hand, respondents in the age of 41 and more give this factor the top priority and actively pursue this information. Another disparity occurred in a product promoted by an influencer or celebrity, where the situation is completely opposite. The age categories up to 25 years and 2640 years take this factor into serious consideration, whereas respondents of 41 years and more give this aspect no attention whatsoever.

The analysis suggested marked differences in purchasing decorative cosmetics throughout age groups caused by internal motives and external stimuli. The decisive factor always depends on individual consumers with the biggest differences predominating in the youngest category.

\section{Conclusion}

The submitted article aimed at decision-making factors of consumer behavior in purchasing decorative cosmetics by analyzing internal motives and external stimuli to encourage the purchase.

The research objective was fulfilled. The information from the interviews provided us with findings about the most frequent internal motives and external factors involved in the purchase of decorative cosmetics. We were thereby able to answer the formulated research questions. The classification into separate age groups allowed more accurate results thanks to which we could identify substantial differences in the purchase behavior. Component pie graphs illustrate the most frequent incentives and external stimuli encouraging customers of individual age categories to the purchase. The research revealed that it is essential to precisely determine the group of customers the company wants to aim at, as different categories succumb to different factors.

All the same, the obtained results cannot be valid for a long time, as external influencing factors are subject to rapid changes. The outer stimuli largely depend on the technological and marketing development. Namely influencering represents a very popular and effective factor. Although this type of marketing had not been an exception before, modern social networks attached profound significance to this kind of persuasion. It is thereby imperative to incessantly monitor the market and new technological development to permanently restore the supply according to the most persuasive factors.

\section{Literature:}

1. Bočková, K., Škrabánková, J., Hanák, M.: Theory and practice of neuromarketing: analyzing human behavior in 
relation to markets. Emerging Science Journal. 2021, 5(1), 44-56 p. ISSN 2610-9182.

2. Filipe, S., Marques, S. H., Salgueiro, M. D. F.: Customers' relationship with their grocery store: direct and moderating effects from store format and loyalty programs. Journal of Retailing and Consumer Services. 2017, 37, 78-88 p. ISSN 0969-6989.

3. Hamplová, Š.: Kupni chování spotřebitelu při výběru pletové kosmetiky [Consumer buying behavior when choosing skin cosmetics]. Brno: Pedagogická fakulta Masarykovy university [Fakulty of Education of Masaryk University], 2017. Diplomová práce [master's thesis].

4. Kicová, E.: Importance of advertising media attributes in the context of long-term brand building in Slovakia. Littera Scripta. 2020, 13(2), 59-69 p. ISSN 1805-9112.

5. Král, P., Janošková, K., Lazaroiu, G., Šuleř, P.: Impact of selected socio-demographic characteristics on branded product preference in consumer markets. Management \& MarketingChallenges for the Knowledge Society. 2020, 15(4), 570-583 p. ISSN 1842-0206.

6. Maynard, O. M., Mcclernon, F. J., Oliver, J. A., Munafò, M. R.: Using neuroscience to inform tobacco control policy. Nicotine \& Tobacco Research. 2019, 21(6), 739-746 p. ISSN 1469-994X.

7. Mazeed, A. S., Chandra, M., Muralli Mohan, G., Babu, V. H.: Role of social media in customer buying behavior. International Journal of Engineering and Advanced Technology. 2019, 9(1), 2411-2413 p. ISSN 2249-8958.

8. Moya, I., García-Madariaga, J., Blasco, M. F.: What can neuromarketing tell us about food packaging? Foods. 2020, 9(12). ISSN 2304-8158.

9. Nadányiová, M., Klieštiková, J., Olah, J.: Financing of adverts and its impact on the brand value. Littera Scripta. 12(2), 96-107 p. ISSN 1805-9112

10. Novotný, J., Duspiva P.: Factors influencing consumers' buying behavior and their importance for enterprises. $E+M$ Ekonomie a Management. 2014, 17(1), 152-166 p. ISSN 12123609.

11. Porter, T., Potcovaru, A. M., Zaušková, A., Rowland, Z., Grupač, M.: Smartphone addiction risk, anxiety symptom severity, and depression psychopathology. Review of Contemporary Philosophy. 2020, 19, 57-63. ISSN 1841-5261.

12. Slabá, M.: The impact of age on the customers buying behaviour and attitude to price. Littera Scripta. 2019, 12(2), 169177. ISSN 1805-9112.

13. Stankevich, A., Akhunjonov, U., Obrenovic, B.: Explaining the consumer decision-making process: critical literature review. Journal of International Business Research and Marketing. 2017, 2(6), 7-14 p. ISSN 1849-8558.

14. Sun, C.: The research and evaluation of customer relationship management and social responsibility on competitive advantage. Revista de Cercetare si Interventie Sociala. 2020, 69, 131-142 p. ISSN 15833410.

15. Wang, Y., Yu, C.: Social interaction-based consumer decision-making model in social commerce: the role of word of mouth and observational learning. International Journal of Information Management. 2017, 37(3), 179-189 p. ISSN 02684012.

16. Willman-Iivarinen, H.: The future of consumer decision making. European Journal of Futures Research. 2017, 5(1), ISSN 2195-4194.

17. Žák, P., Hasprová, M.: The role of influencers in the consumer decision-making process. 19th International Scientific Conference Globalization and Its Socio- Economic Consequences - Sustainability in the Global-Knowledge Economy. 2019, 74. ISSN 2261-2424.

18. Žilinská, M., Vrbka, J., Kalinová, E.: Does the implementation of loyalty programmes lead to gaining a loyal customer? Ad Alta-Journal of Interdisciplinary Research. 2021, 11(1), 392-396 p. ISSN 1804-7890.

\section{Primary Paper Section: A}

Secondary Paper Section: AO, AH, AE 